Runan Yang*, Nina Takashino and Katsuhito Fuyuki

\title{
Japanese Consumers' Willingness to Pay for Environmentally Friendly Farming Produce Based on Consumer Trustfulness
}

https://doi.org/10.1515/jafio-2020-0036

Received November 30, 2020; accepted April 13, 2021

\begin{abstract}
In the past decade, the market share of environmentally friendly farming (EFF) produce in Japan has witnessed relatively rapid growth. However, consumer awareness and purchasing experience of this agricultural produce are still lagging. To study how awareness of EFF produce influences consumer psychology and purchase decisions, we use ordered logistic regression and choice experiments to analyze 600 survey responses collected through online questionnaires. The results show that information from friends and family can have a positive influence on Japanese consumers' trust in EFF produce. Consumers also show a significant preference for EFF produce in the short term after receiving information about it. By setting up a control group for comparison, we find that, in addition to information, consumer education and income also positively and significantly affect the decision to purchase EFF produce. This study presents a unique perspective between information and consumer decisionmaking and provides targeted solutions for the promotional and marketing strategy problems faced by EFF produce sellers in Japan. We argue that strengthening regional publicity methods such as community events can enhance EFF producers' marketing strategies.
\end{abstract}

Keywords: Japan, choice experiments, Japanese consumers' trustfulness, environmentally friendly produce, marginal willingness to pay

\section{Introduction}

Organic and special cultivation agricultural produce markets are growing steadily in Japan, and they are representative of environmentally friendly farming (EFF)

*Corresponding author: Runan Yang, Tohoku University, Sendai, Japan, E-mail: runan.yang.s4@dc.tohoku.ac.jp. https://orcid.org/ 0000-0002-8081-8923

Nina Takashino and Katsuhito Fuyuki, Tohoku University, Sendai, Japan

Ә Open Access. (c) 2021 Runan Yang et al., published by De Gruyter. ((c)) BY International License. production methods. Japan's Ministry of Agriculture, Forestry and Fisheries (MAFF) (2019) reports that the market size of organic agriculture in the country has grown by $42 \%$ in the last decade, and its acreage has achieved rapid growth of $40 \%$ to 23,000 ha. Alternatively, compared with organic agricultural produce that conforms to MAFF standards, specially cultivated agricultural produce with a relatively relaxed censorship system ${ }^{1}$ is gradually gaining market share. MAFF began implementing special cultivation in 2001, promoting the application of a small amount of chemical pesticides and fertilizers, similar to "Green Food" in China. Compared to the strict land conditions for organic cultivation, those for special cultivation are relatively mild; local governments can set conditions for specially cultivated produce under basic provisions. ${ }^{1}$ The MAFF (2019) data established that, compared with the developed market in Europe, the EFF market in Japan is still in its growth stage. Scholars have conducted considerable research on EFF to help understand and expand the market share of such agricultural produce and enhance farmers' motivation to cultivate. For example, Ogawa (2001) employs the perspective of information economics to analyze consumers' decision problems when purchasing organic agricultural produce. By giving consumers different types of information about the product, their purchase utility of organic produce changes significantly. However, in an analysis of the Japanese organic market, Yano Research Institute Ltd. (2018) notes that there is lack of information about organic food available to consumers, which is a prominent problem in the current EFF produce market. Hosono and Nakashima (2011) show that Japanese consumers lose trust in food production and avoid repurchasing in response to a food safety issue. Takahashi, Todo, and Funaki (2018) use the randomized controlled trial method to illustrate that vending machines using the eco-certified coffee logo can achieve higher sales. MAFF (2019) reports that when Japanese consumers face higher-

1 As per Japanese standards, using synthetic pesticides when growing organic produce is forbidden. However, specially cultivated agricultural produce can use pesticides at a level 50\% below the standard use in normal agricultural produce. https://www.maff.go.jp/j/jas/jas_ kikaku/pdf/tokusai_03.pdf. 
priced EFF produce, trust in the health and safety of the produce is the main driving factor of purchase. Many studies outside of Japan also point out that consumers pay attention to information on EFF produce stores near their residence and often obtain such information through media (Huang et al. 2006; Liu et al. 2012; Pearson, Henryks, and Jones 2011; Rabadán et al. 2020).

In the literature, the theory of planned behavior and structural equation models are widely used to explain consumers' purchase intention and consumption behavior, interpret consumer cognition, and avoid endogenous variables (Carfora et al. 2019; Ngo et al. 2020; Parves et al. 2020; Sadiq et al. 2021; Wang and Tsai 2019). The results of these studies show that trust in healthy farming practices and no pesticides as a mediating variable among consumers play a decisive role in the intention to purchase EFF produce. The transfer of information is crucial in influencing consumer behavior. Hilverda, Kuttschreuter, and Giebels (2017) state that when consumers receive an introduction to EFF produce from experts around them, it enhances their trust in the produce. However, their research does not examine the variable of people around them who are not experts. This approach ignores the substantive actions of consumers, and we conclude that relying solely on psychological approaches such as TPB is not sufficient.

Extant methodologies have other serious limitations. First, although research has examined consumers' access to information, few studies have conducted empirical analysis by simulating information transmission. No other information type has been analyzed, such as information on specially cultivated agricultural produce. It is meaningful to conduct a comparative analysis of consumers' willingness to pay for organic agricultural produce and specially cultivated agricultural produce.

Second, most studies discussed above are limited to addressing the lack of information on EFF produce faced by consumers. They do not focus on more specific issues, such as consumer decision-making, after the information is assessed.

Thus, in this study, we consider the implications of information in consumers' trustfulness and behavior. We design a questionnaire to measure consumers' behavior after they receive information about EFF produce. An ordered logistic regression model is established to analyze the relationship between consumers' trust in EFF produce and information variables; consumers still encounter advertisements and some definitions of EFF produce through media, families, and so on in their daily life. Thereafter, we employ choice experiments (Aizaki and Nishimura 2007, 2008) to analyze how consumers' marginal willingness to pay (MWTP) changes after they receive EFF produce information.

The remainder of this paper is organized as follows: Section 2 describes the study data and research methodology. Section 3 presents the descriptive statistics as well as the results of the ordered logistic regression. Section 4 analyzes the results of the choice experiments. Section 5 concludes the paper and offers recommendations for the EFF market.

\section{Research Method}

\subsection{Data Collection}

We targeted consumers between the ages of 20 and 75 years from across Japan for data collection and focused on obtaining personal attributes such as education, gender, and income. The sample comprised adults who bought fresh vegetables at least once a month. The questionnaire also surveyed the information attributes of consumers and their daily habits of consuming EFF produce. Because of the COVID-19 pandemic, it is difficult to conduct field surveys. Hence, we commissioned ASMARQ Co., Ltd., and used an online questionnaire to collect data per the above requirements. The company randomly sampled 10,000 consumers and obtained 890 valid questionnaires from 1097 respondents (81.13\%). Due to funding constraints, we randomly selected 600 out of these 890 to examine. Then, choice experiments were designed to survey these 600; the data were collected from August 31 to September 2, 2020.

Table 1 presents the descriptive statistics of the personal attributes collected by the survey. The middle-aged and elderly account for the majority of the sample; the distribution of male and female respondents is relatively balanced. In order to analyze whether consumer trust in EFF produce was influenced by minors in the respondents' households, we defined the dummy variables CHILD1 and CHILD2 according to the ages for which education is compulsory in Japan. By observing the variable OLD, we found that about $50 \%$ of respondents lived with their families and were over 60 years old; few families resided with their children.

We attempted to understand the respondents' awareness and consumption of EFF produce with the following questions: "How much do you know about EFF produce?" and "Have you bought EFF produce?" Figures 1 and 2 present the results.

Figure 1 indicates that $71 \%$ of the 600 respondents thought they had a greater than "moderate awareness" of the existence of organic agricultural produce. Further, only 
Table 1: Variable names, definitions, and descriptive statistics $(N=600)$.

\begin{tabular}{|c|c|c|c|}
\hline Variable & Description & Mean & $\begin{array}{l}\text { Std. } \\
\text { Dev. }\end{array}$ \\
\hline AGE & Unit: years & 52.52 & 12.13 \\
\hline GENDER & $0=$ male $; 1=$ female & 0.45 & 0.50 \\
\hline INCOME & Annual income (yen)* & 4.62 & 3.65 \\
\hline EDUC & $\begin{array}{l}\text { Education years: } 1=9 ; 2=12 ; 3=15 \\
4=16 ; 5=18\end{array}$ & 3.34 & 0.93 \\
\hline CHILD1 & $\begin{array}{l}\text { Have children under } 12 \text { and in the house- } \\
\text { hold. } 0=\text { no; } 1=\text { yes }\end{array}$ & 0.15 & 0.35 \\
\hline CHILD2 & $\begin{array}{l}\text { Have children older } 13 \text { and in the house- } \\
\text { hold. } 0=\text { no; } 1=\text { yes }\end{array}$ & 0.10 & 0.30 \\
\hline OLD & $\begin{array}{l}\text { Including you, is there anyone in your } \\
\text { household who is } 60 \text { and older? } \\
0=\text { no; } 1 \text { = yes }\end{array}$ & 0.50 & 0.50 \\
\hline
\end{tabular}

*1.5 = less than 2 million; $2.5=2-3$ million; $3.5=3-4$ million; $4.5=4-5$ million; $5.5=5-6$ million; $6.5=6-7$ million; $7.5=7-8$ million; $8.5=8-9$ million; $9.5=9=10$ million; $12.5=10-15$ million; $17.5=15-20$ million; $22.5=$ over 20 million.

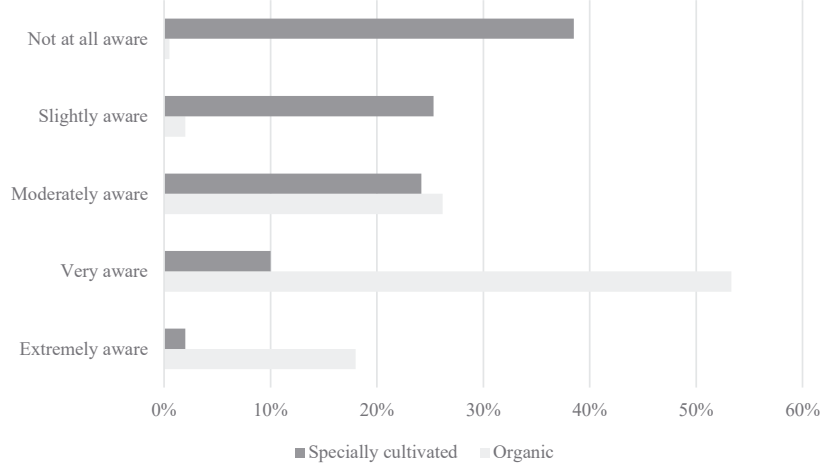

Figure 1: Respondents' awareness of organic and specially cultivated produce. Source: Online Survey 2020.

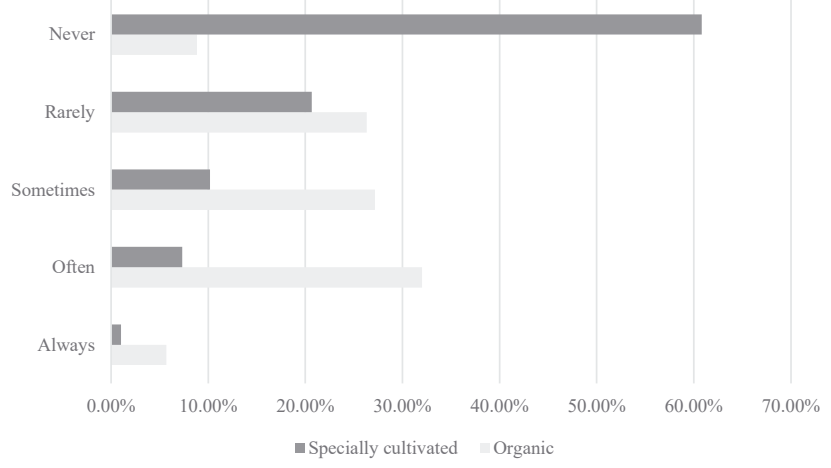

Figure 2: Respondents' buying experience with organic and specially cultivated produce. Source: Online Survey 2020.
$12 \%$ of consumers said they were "very aware" or "extremely aware" of specially cultivated agricultural produce, and over $60 \%$ of respondents had never bought such produce. Figure 2 shows that $37.7 \%$ of the consumers "often" or "always" bought organic agricultural produce, and only $8.8 \%$ had never bought organic agricultural produce. Thus, after years of promotion and development, organic agricultural produce is finally being accepted by consumers, indicating rapid development of the organic agricultural market. However, consumers still have a low level of awareness and show low demand for specially cultivated agricultural produce.

\subsection{Ordered Logistic Model}

The survey questions were rated using a five-point Likert scale. We surveyed consumers regarding their trust in EFF produce and the amount of information they receive about EFF produce from avenues such as social media, family and friends, and stores. "Trust in organic agricultural produce" and "trust in specially cultivated agricultural produce" were used as dependent variables with respect to the two groups "TRUST_ORGANIC" and "TRUST_SPEC." This means that the consumer trusts that the cultivation methods advertised for this commodity are real and meaningful and the resulting produce's characteristics differ from those of ordinary agricultural produce. Greene (2008) notes that the ordered logistic model should be used for ordinal categorical variables. Thus, the general ordered logit model is adopted, as specified in Eq. (1):

$$
\operatorname{logit}\left(p_{j}\right)=\ln \left(\frac{p_{j}}{1-p_{j}}\right)=\alpha_{j}+\beta_{1} x_{1}+\beta_{2} x_{2}+\cdots+\beta_{n} x_{i}
$$

The cumulative probability function formula is as follows:

$$
P\left(Y_{i}>j\right)=\frac{\exp \left(\alpha_{j}+X_{i} \beta\right)}{1+\left\{\exp \left(\alpha_{j}+X_{i} \beta\right)\right\}}, j=1,2, \ldots \ldots, K-1
$$

where $\alpha_{j}$ is a constant term, $p_{j}$ is the cumulative probability of the first $j$ values, and $K$ is the cumulative variable with grade order. In this thesis, jis a five-level variable. The ordered logit model should satisfy the parallelism hypothesis (Long 1997; Yagishita and Fuwa 2016). Thus, the "brant" instruction in Stata 14 for the parallelism test is used in this analysis. The explained variable $Y_{i}$ and explanatory variable $x_{i}$ are set as follows:

$Y($ trustfulness $)=f($ personal, cognitive, information $)$. 
In cognitive attributes, we include consumers' recognition of produce freshness and price because it strongly affects consumer choice for EFF produce (Britwum, Bernard, and Albrecht 2021; MAFF 2019). Similarly, many studies indicate that when buying organic produce, consumers look for traceability and the origin. Table 2 shows the detailed variable terms from previous studies.

Sakai et al. (2018) use personal attributes and external environmental variables as exogenous variables in an ordered logistic regression to analyze consumers' evaluation of fish produce. This study uses the variable "FRIEND" to investigate whether people other than experts influence consumers' trust in EFF products, which is the main factor we want to investigate based on Hilverda, Kuttschreuter, and Giebels' (2017) study. However, it should be noted that people may not always be able to contact experts and scholars in daily life compared to contacting their family and friends, who interact more closely. To avoid endogeneity, this study adds four exogenous factors to the

Table 2: Ordered logistic regression model variable names.

\begin{tabular}{|c|c|c|c|}
\hline Variable Name & & $\begin{array}{l}\text { Measurement } \\
\text { items }\end{array}$ & Reference \\
\hline Trustfulness* & TRUST & $\begin{array}{l}\text { Do you trust eco- } \\
\text { friendly produce } \\
\text { (organic/special)? }\end{array}$ & $\begin{array}{l}\text { Roitner-Scho- } \\
\text { besberger 2008; } \\
\text { Saba and Messina } \\
\text { 2003; Shafie and } \\
\text { Rennie } 2012\end{array}$ \\
\hline \multirow[t]{3}{*}{ Cognitive $^{\star \star}$} & PRICE & $\begin{array}{l}\text { I pay attention to } \\
\text { the price when I } \\
\text { buy vegetables. }\end{array}$ & $\begin{array}{l}\text { Mineki et al. 2001; } \\
\text { Prescott et al. 2002; } \\
\text { Vitters } \varnothing \text { and Tange- } \\
\text { land } 2015\end{array}$ \\
\hline & FRESH & $\begin{array}{l}\text { I pay attention to } \\
\text { freshness when I } \\
\text { buy vegetables. }\end{array}$ & $\begin{array}{l}\text { Ngo et al. 2020; } \\
\text { Wang and Tsai } 2019\end{array}$ \\
\hline & ORIGIN & $\begin{array}{l}\text { I pay attention to } \\
\text { origin when I buy } \\
\text { vegetables. }\end{array}$ & $\begin{array}{l}\text { Liu 2020; Ohashi, } \\
\text { Yagi, and Naito } 2017\end{array}$ \\
\hline \multirow[t]{4}{*}{$\begin{array}{l}\text { Information } \star \star \\
\text { (organic/ } \\
\text { special) }\end{array}$} & SHOP & $\begin{array}{l}\text { There are stores } \\
\text { near me that sell } \\
\text { EFF produce. }\end{array}$ & $\begin{array}{l}\text { Rabadán et al. 2020; } \\
\text { Takahashi, Todo, and } \\
\text { Funaki 2018; }\end{array}$ \\
\hline & MEDIA & $\begin{array}{l}\text { I see a lot of infor- } \\
\text { mation in the me- } \\
\text { dia about EFF } \\
\text { produce. }\end{array}$ & $\begin{array}{l}\text { Huang et al. 2006; } \\
\text { Liu et al. 2012; Pear- } \\
\text { son, Henryks, and } \\
\text { Jones } 2011\end{array}$ \\
\hline & FRIEND & $\begin{array}{l}\text { My family mem- } \\
\text { bers and friends } \\
\text { regularly buy EFF } \\
\text { produce. }\end{array}$ & $\begin{array}{l}\text { Hilverda, Kutts- } \\
\text { chreuter, and Giebels } \\
(2017)\end{array}$ \\
\hline & WEB & $\begin{array}{l}\text { I know EFF produce } \\
\text { can be ordered } \\
\text { online. }\end{array}$ & $\begin{array}{l}\text { Castle et al. 2019; } \\
\text { Moriuchi and Taka- } \\
\text { hashi } 2018\end{array}$ \\
\hline
\end{tabular}

${ }^{\star} 1=$ no trust to $5=$ very trusting $* \star 1=$ strongly disagree; 2 = disagree; $3=$ neutral; $4=$ agree; $5=$ strongly agree. information attributes in the model: "SHOP," "MEDIA," "FRIEND," and "WEB." These variables measured the level of consumers' exogenous sources of information about EFF produce, such as whether there are stores nearby that sell EFF produce (SHOP) and whether they are aware of online ordering (WEB) (see Table 2), by grouped regression through the explained variables "TRUST_ORGA" and "TRUST_SPEC" - denoting "the trust level in organic produce" and "the trust level in specially cultivated produce," respectively. Thus, we hypothesize the following:

H1: SHOP_ORGA is positively correlated with trust in EFF produce.

H2: SHOP_SPEC is positively correlated with trust in EFF produce.

H3: MEDIA_ORGA is positively correlated with trust in EFF produce.

H4: MEDIA_SPEC is positively correlated with trust in EFF produce.

H5: FRIEND_ORGA is positively correlated with trust in EFF produce.

H6: FRIEND_SPEC is positively correlated with trust in EFF produce.

H7: WEB_ORGA is positively correlated with trust in EFF produce.

H8: WEB_SPEC is positively correlated with trust in EFF produce

If these hypotheses hold, it demonstrates that information can influence consumer trust in agricultural produce, providing us with an empirical basis for the choice experiments.

\subsection{Choice Experiments}

We reproduced choice experiments (Aizaki and Nishimura 2008) through R. The conditional logit model allows for mutual independence and heterogeneity among consumers so that their personal attributes can be added to the model as interactions to measure MWTP (Aizaki 2005; Hoffman and Duncan 1988). Therefore, the model can be more effective in verifying whether the psychological trustworthiness of consumers is consistent with their 
preferences in actual consumption behavior. The utility function of the conditional logit model is as follows:

$$
U_{n i}=V_{n i}+u_{n i}=\beta x_{n i}+u_{n i}
$$

Here, $i$ is a chosen commodity attribution, $V_{n i}$ is the observable utility, and $u_{n i}$ is the unobservable error term. $X_{n i}$ is the scenario characteristic of the random variable that consumer $n$ should choose, and the coefficient $\beta$ of $X_{n i}$ is used to describe individual differences in utility equal to $V_{n i}$, obeying a normal distribution to allow for meanindependent analysis with individual attributes. The probability distribution function for a consumer $n$ to choose under the fixed scenario $j$ option is

$$
P_{n i}=\frac{\exp \left(\beta x_{n i}\right)}{\sum_{j} \exp \left(\beta x_{n i}\right)}
$$

The conditional logistic function uses the maximum likelihood method for parameter estimation; the formula is shown in Eq. (6), where the dummy variable $\delta_{n}^{i}$ takes the value of 1 when a good $i$ is selected by individual $n$ and 0 otherwise.

$$
\ln L=\sum_{n=1}^{N} \sum_{i} \delta_{n}^{i} \ln \frac{\exp \left(\beta x_{n i}\right)}{\sum_{j} \exp \left(\beta x_{n j}\right)}
$$

Consumer MWTP represents the price that the consumer is willing to pay for an additional unit of a good. It consists of the negative ratio of commodity category attributes parameter $\beta_{A}$ to the price parameter $\beta_{p}$. Equation (8) gives the MWTP.

$$
\text { MWTP }=-\frac{\beta_{A}}{\beta_{P}} .
$$

Following Ogawa (2001) and Oura et al. (2002), we randomly divide all 600 consumers into four groups that entered choice experiments after reading different information about EFF separately. The information was derived from the relevant definitions published by the MAFF. After receiving different types of information on the definitions of organic and specially cultivated produce respectively by group, we analyzed whether there are significant differences in consumer preferences in different groups. The information read by consumers is shown in Table 3. After reading this information, all consumers received the same questionnaire and made a single choice between three options.

Figure 3 presents the definition of EFF produce that the consumers read. The definitions were copied from MAFF's homepage and translated into English.

We surveyed the EFF produce market price by using statistics released by MAFF in 2018. To compare consumer
Table 3: Reading content by groups.

\begin{tabular}{ll}
\hline Reading content \\
\hline Group A & None \\
Group B & Definition of organic agriculture \\
Group C & Definition of specially cultivated agriculture produce \\
Group D & Definition of organic and specially cultivated agriculture \\
& produce \\
\hline
\end{tabular}

preferences for different types of vegetables, we selected three representative types: root vegetables, Solanaceae vegetables, and leafy vegetables. We thus identified carrots, tomatoes, and cabbage, respectively, as subjects of the study. The prices were set through data analysis and market surveys. Three dummy variables named "ORGA," "SPEC," and "Ordinary" were set as variables. "Ordinary" refers to ordinary agricultural produce cultivated without EFF and set as a base group. Detailed settings are shown in Table 4.

From the permutations of price and category in Table 4, it can be seen that there are $5 \times 3=15$ choices for each vegetable set, and eight questions were selected in this research for each vegetable by orthogonally combining with the R package Algdesign; 24 questions were set in total, and each question was set with a "No choice" option; Appendix 1 contains these results.

Galesic and Bosnjak (2009) contend that having too many options in an online questionnaire is likely to significantly decrease the quality of the questionnaire. To ensure efficiency, before beginning, the respondents were informed that there would be 24 questions and that the total answer time for all questions should be at least $60-$ $90 \mathrm{~s}$. To prevent potential inefficiency caused by a large number of questions, we designed the survey with only two features, "Price" and "Category." Respondents who did not complete the questionnaire, who took less than $30 \mathrm{~s}$ to respond, and who chose the same answer for all 24 questions were disqualified. Figure 4 shows a questionnaire screenshot.

\section{Questionnaire Analysis}

Figures 5 and 6 present a five-level scale of trustfulness and information for the 600 respondents. We find that consumers place a similar level of trust in ORGA and SPEC produce, although more consumers state they have seen information about ORGA in the media. In addition, for the variables SHOP and WEB, more than 260 consumers nearly half of the total surveyed - chose "strongly 


\begin{tabular}{|c|c|}
\hline Organic produce & SPEC produce \\
\hline $\begin{array}{l}\text { Organic produce is based on avoiding the use of } \\
\text { chemically synthesized fertilizers and pesticides, to } \\
\text { bring out the productive power of farmland derived } \\
\text { from the properties of the soil, and reduces the } \\
\text { burden on the environment derived from agricultural } \\
\text { production. } \\
\text { (1) No use of chemical fertilizers or synthetic } \\
\text { agricultural chemicals. } \\
\text { (2) Highly effective in preventing global warming } \\
\text { and conserving biodiversity. } \\
\text { (3) Genetic modification technology is not used. } \\
\text { (4) The registered certification body shall conduct a } \\
\text { survey of farmers at least once a year. } \\
\text { (5) Physical and biological methods are used to } \\
\text { prevent pests and animals. }\end{array}$ & $\begin{array}{l}\text { SPEC produce refers to agricultural products grown } \\
\text { with } 50 \% \text { or less of the use of pesticides and } \\
\mathbf{5 0 \%} \text { or less of the nitrogen content of chemical } \\
\text { fertilizers, compared to the conventional level in } \\
\text { the region where they are produced. } \\
\text { (1) Produce using cultivation methods that reduce } \\
\text { the burden on the environment as much as possible. } \\
\text { (2) Both agricultural chemicals and chemical } \\
\text { fertilizers to be reduced must be reduced. } \\
\text { (3) The calculation of the reduction ratio shall be } \\
\text { based on the level of transparent and fair practices } \\
\text { established by local governments as a comparison } \\
\text { standard. }\end{array}$ \\
\hline
\end{tabular}

Figure 3: Reading content about environmentally friendly farming produce. Source: MAFF: https://www.maff.go.jp/j/ seisan/kankyo/yuuki/; https://www.maff. go.jp/j/jas/jas_kikaku/tokusai_a.html.
Table 4: Choice experiment option settings and produce specifications.

\begin{tabular}{llll}
\hline & Cabbage & Tomato & Carrots \\
\hline Price & $140,170,200$, & $170,210,250$, & $200,250,300$, \\
(yen) & 230,260 & 290,330 & 350,400 \\
Category & ORGA/ordinary/ & ORGA/ordinary/ & ORGA/ordinary/ \\
& SPEC & SPEC & SPEC \\
Weight & $(500 \mathrm{~g} /$ package $)$ & $(350 \mathrm{~g} /$ package $)$ & $(500 \mathrm{~g} /$ package $)$ \\
\hline
\end{tabular}

B1.

次のニつのトマトが眅売されています。どちらを睦入したいですか。

睡入したい方選んでください。「どちらも買わない」という選択もできます。

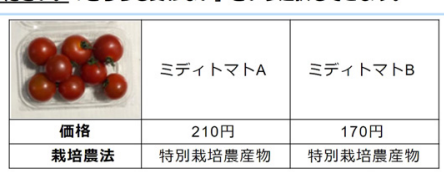

(ひとつだけ）【必須]

ミディトマトA

ミディトマトB

どちらも買わない

Figure 4: Screenshot of online questionnaire.

disagree" for specially cultivated produce. In the case of organic produce, more consumers tended not to choose the extreme "strongly disagree" but to choose "disagree" and "neutral." The number of relatives who receive information from their friends about organic agricultural produce is significantly higher than for SPEC for the options "agree" and "strongly agree." That is, consumers recognize organic produce more than they recognize specially cultivated produce. Alternatively, most consumers do not have enough information about specially cultivated agricultural produce from outside sources.

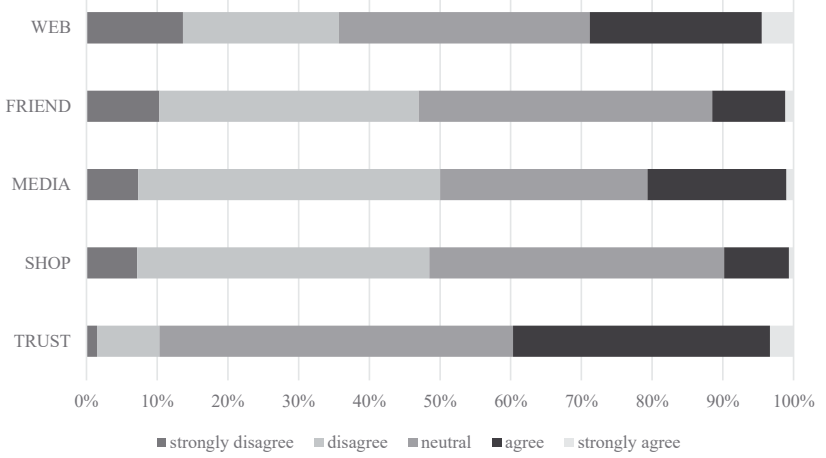

Figure 5: Five-level scale of trustfulness and information about ORGA (sample size: 600). Source: Online Survey, 2020.

\section{Results}

\subsection{Order Logistic Regression}

Table 5 presents the results of the ordered logistic model. We estimated two groups, a total of four models, with group 1 incorporating all information variables and group 2 removing all informative variables except FRIEND. Both sets of regressions use the heteroskedasticity-robust standard error. The results show that Model 2 failed the parallelism test. Finally, we chose Models 1 and 4 as the subjects because they can explain the results in greater detail than Models 2 and 3.

In Table 5, there is a significant positive correlation between "TRUST" and "MEDIA_ORGA" for $p<0.10$, and "FRIEND_ORGA" is also positive for $p<0.01$, indicating significance, but adding information about EFF produce available from nearby and online markets did not reject $\mathrm{H3}$ and H5. Thus, the density of information from media and friends increases, indicating a positive effect on trust in organic food. 


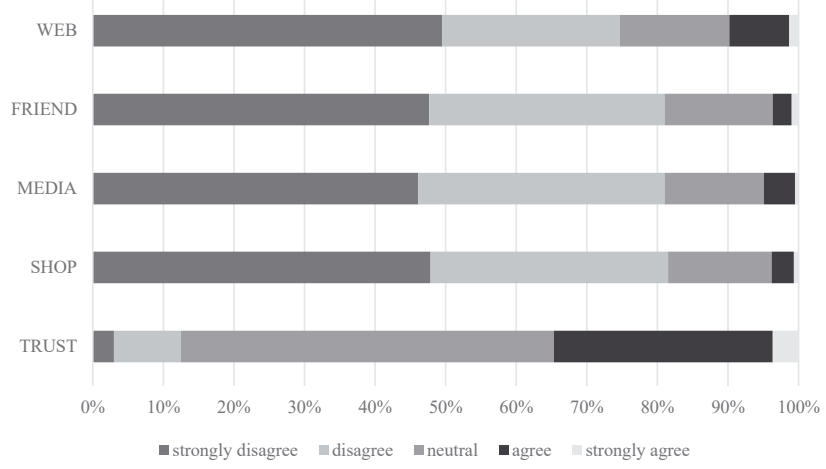

Figure 6: Five-level scale of trustfulness and information about SPEC (sample size: 600). Source: Online Survey 2020.

We thus confirm Sato et al.'s (2005) conclusion in Model 1; the significance of CHILD1 indicates that families with children had more trust in organic produce because of health concerns. This behavior is positively associated with trustworthiness. Conversely, in Model 4, we can see that the result for CHILD2 is still significant, but it had a negative sign compared with CHILD1 in Model 1. We believe that the age of 12 years, when Japanese children graduate from elementary school and enter junior high school, is when parents become inclined to invest more time and energy in the education rather than in the choice of EFF produce.

The results for specially cultivated agricultural produce in Model four show that in the information category, only the results for the explanatory variable "FRIEND_ SPEC" failed to reject H6. This is because of the lack of consumer awareness regarding specially cultivated agricultural produce.

Tables 6 and 7 present the marginal effects of the significant variable in Models 1 and 4. The results show that information from friends and family members and the origin of EFF produce effectively increased consumers' trust in both models. From AGE in Tables 6 and 7, we see that although there is a marginal decrease in consumer trust in EFF foods with age, its ability to influence is not significant. From CHILD1 and CHILD2 in Tables 6 and 7, the

Table 5: Results of the ordered logistic regression.

\begin{tabular}{|c|c|c|c|c|}
\hline & \multicolumn{4}{|c|}{ Dependent variable } \\
\hline & \multicolumn{2}{|c|}{ GROUP 1} & \multicolumn{2}{|c|}{ GROUP 2} \\
\hline & $\begin{array}{r}\text { Model } 1 \\
\text { TRUST_ORGA }\end{array}$ & $\begin{array}{r}\text { Model } 2 \\
\text { TRUST_SPEC }\end{array}$ & $\begin{array}{r}\text { Model } 3 \\
\text { TRUST_ORGA }\end{array}$ & $\begin{array}{r}\text { Model } 4 \\
\text { TRUST_SPEC }\end{array}$ \\
\hline SHOP_ORGA & 0.218 & - & - & - \\
\hline MEDIA_ORGA & $0.231^{*}$ & - & - & - \\
\hline FRIEND_ORGA & $0.654^{\star \star \star}$ & - & $0.821^{\star \star \star}$ & - \\
\hline WEB_ORGANIC & -0.130 & - & - & - \\
\hline PRICE & 0.017 & 0.073 & 0.006 & 0.069 \\
\hline FRESH & $0.225^{\star}$ & 0.191 & $0.208^{\star}$ & 0.214 \\
\hline ORIGIN & $0.261^{\star \star \star}$ & $0.269^{\star \star \star}$ & $0.260^{\star \star \star}$ & $0.279^{\star \star \star}$ \\
\hline AGE & $-0.028^{\star \star \star}$ & $-0.021^{\star \star}$ & $-0.293^{\star \star \star}$ & $-0.020^{\star \star}$ \\
\hline GENDER & 0.007 & 0.110 & -0.085 & 0.134 \\
\hline INCOME & 0.010 & 0.016 & 0.014 & 0.015 \\
\hline EDUC & 0.021 & -0.036 & 0.018 & -0.034 \\
\hline CHILD1 & $0.506^{\star \star}$ & 0.259 & $0.474^{\star}$ & 0.235 \\
\hline CHILD2 & -0.257 & $-0.640^{\star \star}$ & -0.236 & $-0.598^{\star \star \star}$ \\
\hline OLD & -0.028 & -0.187 & -0.073 & -0.159 \\
\hline SHOP_SPEC & - & -0.157 & - & - \\
\hline MEDIA_SPEC & - & 0.106 & - & - \\
\hline FRIEND_SPEC & - & $0.539^{\star \star \star}$ & - & $0.694^{\star \star \star}$ \\
\hline WEB_SPEC & - & $0.240^{\star \star}$ & - & - \\
\hline Observations & 600 & 600 & 600 & 600 \\
\hline Parallel-chi ${ }^{2 a}$ & 50.25 & $72.25^{\star \star \star}$ & 39.69 & 41.32 \\
\hline$p>$ chi $^{2}$-parallel & 0.179 & 0.003 & 0.197 & 0.152 \\
\hline VIF & 1.44 & 1.89 & 1.31 & 1.31 \\
\hline$p>\mathrm{chi}^{2}$ & 0.000 & 0.000 & 0.000 & 0.000 \\
\hline Pseudo- $R^{2}$ & 0.105 & 0.083 & 0.099 & 0.079 \\
\hline
\end{tabular}

${ }^{\mathrm{a}} \mathrm{A}$ significant test statistic provides evidence that the parallel regression assumption has been violated. ${ }^{\star} p<0.10,{ }^{\star \star} p<0.05,{ }^{\star \star \star} p<0.01$. 
Table 6: Marginal effects of the ordered logistic regression in Model 1.

\begin{tabular}{|c|c|c|c|c|c|}
\hline Trust level & 1 & 2 & 3 & 4 & 5 \\
\hline MEDIA_ORGA & -0.003 & $-0.016^{*}$ & $-0.026^{\star}$ & $0.038^{\star}$ & $0.007^{\star}$ \\
\hline FRIEND_ORGA & $-0.010^{\star \star}$ & $-0.046^{\star \star \star}$ & $-0.073^{\star \star \star}$ & $0.109^{\star \star \star}$ & $0.020 * \star \star$ \\
\hline FRESH & -0.003 & $-0.016^{\star}$ & $-0.025^{\star}$ & $0.038^{*}$ & $0.007^{\star}$ \\
\hline ORIGIN & $-0.004^{\star \star}$ & $-0.019^{\star \star \star}$ & $-0.029^{\star \star \star}$ & $0.044^{\star \star \star}$ & $0.008^{\star \star \star}$ \\
\hline AGE & $0.000^{\star \star}$ & $0.002^{\star \star \star}$ & $0.003^{\star \star \star}$ & $-0.005^{\star \star \star}$ & $-0.001^{\star \star \star}$ \\
\hline CHILD1 & $-0.008^{\star}$ & $-0.036^{\star \star}$ & $-0.057^{\star \star}$ & $0.085^{\star \star}$ & $0.015^{\star \star}$ \\
\hline
\end{tabular}

${ }^{\star} p<0.10,{ }^{\star \star} p<0.05,{ }^{\star \star *} p<0.01$.

marginal effect of trust in organic food tends to increase for households with children at the ages for which education is compulsory; however, households with children who have completed their compulsory education show a marginal decreasing effect of trust in specially cultivated produce.

Simultaneously, the significance of "FRIEND_ORGA" and "FRIEND_SPEC" indicates that, among the variables affecting trust in EFF produce, the influence of family and friends is strong and positive among Japanese customers. Thus, media information (H3) also has a positive effect on trust in organic produce. This result explains the positive effect of the information variables on consumers' trust in their psychology. It simultaneously influences purchasing decisions (Hosono and Nakajima 2011).

Although we can see that Japanese consumers are concerned about the origin of EFF produce, we were not surprised to find that the freshness variable is significant in organic produce and not in specially cultivated produce. We concluded that since consumers' knowledge of specially cultivated produce is not as rich as that of organic produce, it would influence their decision making when answering the questionnaire. Therefore, for operators selling EFF produce, paying attention to the origin of what they sell is crucial, and the freshness of the produce cannot be neglected either.

Based on the above conclusion, we simulate the transmission of information through the choice experiments to determine the influence of information on consumer decision-making.

\subsection{Choice Experiments}

\subsubsection{No Interaction and MWTP}

From the previous section, we know that consumers' information and their sense of trust are positively correlated. Taniguchi (2012) shows that this trustworthiness is why consumers choose EFF produce. In this section, we show the results of the choice experiment method to further investigate how detailed information affects consumers' decisions.

The conditional logistic regressions based on the choice experiments are shown in Table 8, wherein the interaction terms of personal attributes are not added, but the consumers' choices of different produce are collected directly; the dummy variable "Ordinary" is used as a base group in this regression.

To compare the significant differences among the coefficients within groups, we performed a log-likelihood ratio test for the parameters ORGA and SPEC with the original hypothesis of "ORGA and SPEC are not significantly different" and reported the adjusted R2. Its value was greater than 0.2 , which also verifies the description of Aizaki (2007).

Based on the log-likelihood ratio test, some coefficients failed to reject the null hypothesis, which implies that the comparison of these coefficients is meaningless; this phenomenon was particularly significant in the cabbage group. ${ }^{2}$ MAFF data show that since fewer stores sell EFF cabbage than those selling tomatoes and carrots, consumers are not very sensitive to the attributes of cabbage.

The control group, Group A, did not receive any information and had different preferences for the two commodities. These results imply that consumers prefer specially cultivated produce to organic produce.

Group B consumers who read only information about organic produce exhibit positive significance with respect to the explanatory variables when choosing tomatoes and carrots. However, in the choice of carrots, Group B consumers preferred SPEC produce.

Group C consumers who received information only on SPEC produce also changed their product preferences as

\footnotetext{
2 In 2016, 42, 66, and 414 stores were selling EFF produce of cabbage, tomatoes, and carrots, respectively.

https://www.e-stat.go.jp/stat-search/files? page $=1 \&$ layout $=$ dataset $\&$ toukei $=00500235 \&$ kikan $=00500 \&$ stat infid $=000031556054$.
} 
Table 7: Marginal effects of the ordered logistic regression in Model 4.

\begin{tabular}{lrrrrr}
\hline Trust level & 1 & $\mathbf{2}$ & $\mathbf{3}$ & $\mathbf{4}$ \\
\hline FRIEND_SPEC & $-0.020^{\star \star \star}$ & $-0.051^{\star \star \star}$ & $-0.065^{\star \star \star}$ & $0.113^{\star \star \star}$ & $0.022^{\star \star \star}$ \\
ORIGIN & $-0.008^{\star \star \star}$ & $-0.020^{\star \star \star}$ & $-0.026^{\star \star \star}$ & $0.045^{\star \star \star}$ & $0.009^{\star \star \star}$ \\
AGE & $0.001^{\star \star}$ & $0.001^{\star \star}$ & $0.002^{\star \star}$ & $-0.003^{\star \star}$ & $-0.001^{\star \star}$ \\
CHILD2 & $0.017^{\star}$ & $0.044^{\star}$ & $0.056^{\star}$ & $-0.097^{\star}$ & $-0.020^{\star}$ \\
\hline
\end{tabular}

${ }^{\star} p<0.10,{ }^{* \star} p<0.05,{ }^{\star \star *} p<0.01$.

Table 8: Results based on the choice experiments.

\section{Dependent variable}

\section{CHOICE}

\begin{tabular}{|c|c|c|c|c|c|}
\hline & & A & B & C & D \\
\hline \multirow[t]{4}{*}{ Cabbage } & ASC & $7.346^{\star \star \star}$ & $6.424^{\star \star \star}$ & $8.470^{\star \star \star}$ & $7.245^{\star \star \star}$ \\
\hline & PRICE & $-0.031^{\star \star \star}$ & $-0.025^{\star \star \star}$ & $-0.035^{\star \star \star}$ & $-0.030^{\star \star \star}$ \\
\hline & ORGA & $1.286^{\star \star \star}$ & $1.151^{\star \star \star}$ & $1.330^{\star \star \star}$ & $1.178^{\star \star \star}$ \\
\hline & SPEC & $1.107^{\star \star \star}$ & $1.031^{\star \star \star}$ & 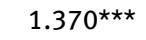 & $1.125^{\star \star \star}$ \\
\hline $\operatorname{Adj}-R^{2}$ & & 0.398 & 0.358 & 0.469 & 0.391 \\
\hline Loglit- $x^{2}(1)$ & & 1.317 & 0.806 & 0.052 & 0.125 \\
\hline \multirow[t]{4}{*}{ Tomato } & ASC & $6.523^{\star \star \star}$ & $6.328^{\star \star \star}$ & $8.110^{\star \star \star}$ & $6.217^{\star \star \star}$ \\
\hline & PRICE & $-0.023^{\star \star \star}$ & $-0.020^{\star \star \star}$ & $-0.026^{\star \star \star}$ & $-0.021^{\star \star \star}$ \\
\hline & ORGA & $0.804^{\star \star \star}$ & $0.952^{\star \star \star}$ & $0.884^{\star \star \star}$ & $0.764^{\star \star \star}$ \\
\hline & SPEC & $1.077^{\star \star \star}$ & $0.760^{\star \star \star}$ & $1.160^{\star \star \star}$ & $0.184^{\star \star \star}$ \\
\hline $\operatorname{Adj}-R^{2}$ & & 0.391 & 0.357 & 0.496 & 0.350 \\
\hline Loglit- $x^{2}(1)$ & & $3.127^{\star}$ & $2.757^{\star}$ & $2.903^{*}$ & $4.114^{\star \star}$ \\
\hline \multirow[t]{4}{*}{ Carrot } & ASC & $5.456^{\star \star \star}$ & $5.223^{\star \star \star}$ & $7.463^{\star \star \star}$ & $6.135^{\star \star \star}$ \\
\hline & PRICE & $-0.019^{\star \star \star}$ & $-0.016^{\star \star \star}$ & $-0.024^{\star \star \star}$ & $-0.020 * \star \star$ \\
\hline & ORGA & 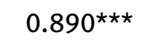 & 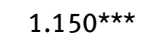 & $1.237^{\star \star \star}$ & $0.918^{\star \star \star}$ \\
\hline & SPEC & $1.194^{\star \star \star}$ & $1.390 * \star \star$ & $1.582^{\star \star \star}$ & $1.091^{\star \star \star}$ \\
\hline $\operatorname{Adj}-R^{2}$ & & 0.274 & 0.303 & 0.413 & 0.320 \\
\hline Loglit- $x^{2}(1)$ & & $5.331 * \star$ & $3.956^{\star \star}$ & $5.429^{\star \star}$ & 1.681 \\
\hline Observations & & 3600 & 3600 & 3600 & 3600 \\
\hline
\end{tabular}

${ }^{\star} p<0.10,{ }^{\star \star} p<0.05,{ }^{\star \star \star} p<0.01$.

expected. In addition to the coefficients of SPEC, they were also all higher than the coefficients of ORGA in the same group of tomato and carrot. Thus, consumers developed a desire to consume SPEC produce in the short term after understanding this produce.

For Group D consumers who read all the information, the coefficient of 0.764 for organic tomatoes was higher than that of 0.184 for specially cultivated tomatoes. After reading all EFF information, consumers likely preferred to choose organic tomatoes over specially cultivated ones.

The price coefficients for all commodities are significant for all four groups of consumers, that is, consumers tended to choose cheaper vegetables. This result confirms the economic attribute of vegetables as inelastic produce. Regardless of whether it is organic or specially cultivated, reducing the cost of such agricultural produce is a primary concern. Consumer MWTP can be obtained according to Eq. (8). The results are shown in Table 9.

Table 9 indicates that the consumers' sensitivity to information differs for varying types of EFF produce; this manifestation is particularly evident for tomatoes. Group A, which did not receive information, was more likely to pay for the SPEC tomatoes, while Group B, which received the organic definition, showed a clear reversal of the MWTP coefficient. Group D showed a strong preference for organic tomatoes when consumers read information on both. Group B consumers had a stronger preference for organic tomatoes than for SPEC produce, while Group C consumers had a stronger preference for SPEC tomatoes and carrots than for organic produce.

Overall, we found that consumers' consumption decisions were effectively influenced by the different 
Table 9: Consumers' marginal willingness to pay in all four groups.

\begin{tabular}{llrrrr}
\hline MWTP & \multicolumn{7}{c}{ A } & B & C & D \\
\hline \multirow{2}{*}{ Cabbage } & ORGA & - & - & - & - \\
& SPEC & - & - & - & - \\
Tomato & ORGA & 34.96 & 47.60 & 34.00 & 36.38 \\
& SPEC & 46.83 & 38.00 & 44.62 & 8.76 \\
& ORGA & 46.84 & 78.88 & 51.54 & - \\
& SPEC & 62.84 & 86.88 & 65.92 & - \\
\hline
\end{tabular}

Source: Online Survey 2020.

information given to them, but the real-life impact was even more significant.

When consumers were confronted with organic vegetables less common in their daily lives (like cabbage), they did not show a clear preference for them, even if they received the appropriate information. This shows that, for those engaged in the sales of organic produce, improving information transmission regarding common foods such as tomatoes, raw goods, salad, or fruit could more easily facilitate consumers' understanding and change their preferences. However, when confronted with the reality of more common EFF vegetables (like the carrot), consumers already hold clear judgments, and information does not have a significant impact.

\subsubsection{Choice Experiments with Interaction Terms}

Given our results on the MWTP for the three types of agricultural produce, once consumers receive different information, we consider Takashino, Chiba, and Fuyuki's (2019) argument that the inclusion of interaction terms for personal attributes in the conditional logistic regression under the choice experiments can determine consumers' individual preferences. Hence, we present a regression containing the interaction terms for personal attributes in Tables 10-12.

Further, Tables 10-12 show that for the four groups of consumers, the price remained negatively significant at $p<0.01$, indicating that price is still an important influential factor in consumers' choice of both ordinary and EFF produce. By comparing the regression coefficients of control Group A with those of the other three groups, the individual attribute that influences consumer decisions shifted from education to income. In Table 11, Group B that accesses organic information shows significance in coefficients for ORGA and SPEC. We explain these coefficients by contending that consumers are paying more attention to organic information when purchasing tomatoes.

Tables 11 and 12 show the regression results of purchase preferences for tomatoes and carrots after we added the interaction terms for personal attributes. After the addition of the interaction term, the parameters of ORGA are not significant, except for Group B, which receives information about organic produce. However, in Groups B and $\mathrm{D}$, we find that consumer income shows a significantly positive trend, especially for Group B. As their income increases, their propensity to consume organic food also increases. This result indicates that the target consumer of organic food is still high income, and income has a more significant influence on their consumption decisions than access to information.

By focusing on the personal attributes of consumers in the control group, Group A, we can conclude that, without receiving any information, consumers' education level is significant and positively correlated with their choices in purchasing specially cultivated produce. Thus, among individual factors, the more educated the consumer is, the more understanding they have of EFF produce and the more willing they are to pay.

Overall, consumers' willingness in different vegetables changes differently after receiving the information, and the significance of some individual variables also shows strong differences compared with the control group, with the coefficient INCOME reflecting a positive correlation with their choices after receiving information.

\section{Conclusion}

The results of this study show that information can affect both psychology and behavior when consumers decide to purchase EFF produce. Compared with media, the information about EFF produce obtained through family and friends leaves a deeper and more positive impression on consumers. However, consumers' consumption preferences toward EFF produce are affected by the type of information they receive. The most important factor influencing consumers' purchase of EFF produce is still prices. However, this study reveals that consumers' consumption decisions change significantly in a short time after they receive more information. Before receiving information, education influences consumers' decisions positively. The purchase behavior of consumers who 
Table 10: Results based on the interaction: Cabbage.

\begin{tabular}{|c|c|c|c|c|c|}
\hline \multicolumn{6}{|c|}{ Dependent variable } \\
\hline \multicolumn{6}{|l|}{ CHOICE } \\
\hline & & A & B & C & D \\
\hline \multirow[t]{12}{*}{ Cabbage } & ASC & $4.054^{\star \star \star}$ & 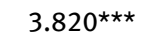 & 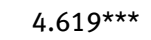 & $4.001^{\star \star \star}$ \\
\hline & PRICE & $-0.963^{\star \star \star}$ & $-0.763^{\star \star \star}$ & $-1.066^{\star \star \star}$ & $-0.917^{\star \star \star}$ \\
\hline & ORGA & 0.460 & 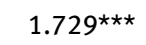 & $1.206^{*}$ & -0.693 \\
\hline & SPEC & -1.057 & 1.024 & $3.213^{\star \star}$ & 0.132 \\
\hline & O_AGE & 0.009 & $-0.020^{\star \star \star}$ & 0.003 & 0.020 ** \\
\hline & O_GENDE & -0.102 & -0.050 & -0.242 & $0.737^{\star \star \star}$ \\
\hline & O_INCOM & -0.032 & $0.120 * \star \star$ & -0.014 & $0.079^{\star \star \star}$ \\
\hline & O_EDUC & $0.195^{\star}$ & -0.028 & 0.047 & 0.037 \\
\hline & S_AGE & 0.017 & $-0.022^{\star}$ & -0.021 & 0.004 \\
\hline & S_GENDE & $-0.832^{\star}$ & 0.288 & $-0.749^{\star}$ & $-0.619^{*}$ \\
\hline & S_INCOM & $-0.129 *$ & $0.155^{\star \star \star}$ & -0.037 & $0.116^{\star \star}$ \\
\hline & S_EDUC & $0.683^{\star \star \star}$ & 0.095 & -0.054 & 0.009 \\
\hline Observations & & 3600 & 3600 & 3600 & 3600 \\
\hline$R^{2}$ & & 0.260 & 0.260 & 0.242 & 0.293 \\
\hline
\end{tabular}

${ }^{\star} p<0.10,{ }^{\star \star} p<0.05,{ }^{\star \star \star} p<0.01$.

Table 11: Results based on the interaction: Tomato.

\begin{tabular}{|c|c|c|c|c|c|}
\hline \multicolumn{6}{|c|}{ Dependent variable } \\
\hline \multicolumn{6}{|l|}{ CHOICE } \\
\hline & & A & B & C & D \\
\hline \multirow[t]{12}{*}{ Tomato } & ASC & 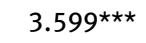 & $3.764^{\star \star \star}$ & 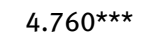 & $3.488^{\star \star \star}$ \\
\hline & PRICE & $-0.918^{\star \star \star}$ & $-0.824^{\star \star \star}$ & $-1.059^{\star \star \star}$ & 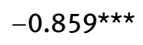 \\
\hline & ORGA & -0.068 & $1.280^{\star \star}$ & 0.399 & 0.095 \\
\hline & SPEC & $-1.468^{\star}$ & $1.392^{\star}$ & 1.164 & 0.056 \\
\hline & O_AGE & 0.008 & $-0.013^{\star}$ & 0.003 & 0.008 \\
\hline & O_GENDE & -0.239 & -0.099 & $-0.494^{\star \star}$ & 0.237 \\
\hline & O_INCOM & 0.028 & $0.098^{\star \star \star}$ & 0.001 & $0.106^{\star \star \star}$ \\
\hline & O_EDUC & 0.145 & -0.026 & 0.159 & -0.099 \\
\hline & S_AGE & 0.017 & -0.008 & -0.005 & -0.000 \\
\hline & S_GENDE & 0.360 & 0.037 & -0.479 & -0.001 \\
\hline & S_INCOM & -0.045 & 0.056 & -0.021 & $0.081^{\star}$ \\
\hline & S_EDUC & $0.537^{\star \star \star}$ & -0.162 & 0.171 & 0.121 \\
\hline Observations & & 3600 & 3600 & 3600 & 3600 \\
\hline$R^{2}$ & & 0.255 & 0.255 & 0.238 & 0.308 \\
\hline
\end{tabular}

${ }^{\star} p<0.10,{ }^{* \star} p<0.05,{ }^{\star \star *} p<0.01$.

receive information about EFF produce also positively correlates to their income.

Finally, our results have certain limitations. First, we only used the ordinary ordered logistic model for regression, according to Lian, Wensu, and Bihong (2014), to enhance the significance of the model. The endogeneity problems of ordinary logit and ordinary probit models deserve further analysis. Second, because of space constraints, we excluded the regional interaction terms, although we had collected regional data. We hope to include regional factors in further research to compare consumers' preferences in different regions. Third, the information about EFF produce that the respondents read was drawn from MAFF's definitions instead of popular advertisements that carry slogans such as "pesticide-free agricultural produce," a label which is technically prohibited by law. Hence, there is a discrepancy between this study and some hyperbolic web slogans; we found that 
Table 12: Results based on the interaction: Carrot.

\begin{tabular}{|c|c|c|c|c|c|}
\hline \multicolumn{6}{|c|}{ Dependent variable } \\
\hline \multicolumn{6}{|l|}{ CHOICE } \\
\hline & & A & B & C & D \\
\hline \multirow[t]{12}{*}{ Carrot } & ASC & $2.685^{\star \star \star}$ & $2.855^{\star \star \star}$ & $3.834^{\star \star \star}$ & $3.218^{\star \star \star}$ \\
\hline & PRICE & $-0.942^{\star \star \star}$ & $-0.821 * \star \star$ & $-1.232^{\star \star \star}$ & $-0.994^{\star \star \star}$ \\
\hline & ORGA & -0.039 & $1.287^{\star \star}$ & 0.651 & 0.264 \\
\hline & SPEC & 0.234 & $2.121^{\star \star \star}$ & $1.591^{\star \star}$ & 0.930 \\
\hline & O_AGE & 0.001 & -0.012 & 0.004 & 0.003 \\
\hline & O_GENDE & -0.159 & -0.115 & -0.453 & 0.025 \\
\hline & O_INCOM & 0.059 & $0.069^{\star *}$ & -0.030 & $0.083^{\star *}$ \\
\hline & O_EDUC & $0.227^{\star}$ & 0.066 & 0.209 & 0.036 \\
\hline & S_AGE & 0.002 & $-0.019^{\star \star \star}$ & 0.003 & -0.007 \\
\hline & S_GENDE & -0.162 & -0.255 & $-0.597^{\star \star \star}$ & -0.293 \\
\hline & S_INCOM & 0.036 & $0.109 * \star \star$ & -0.009 & 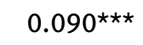 \\
\hline & S_EDUC & $0.255^{\star \star \star}$ & -0.038 & 0.045 & 0.083 \\
\hline Observations & & 3600 & 3600 & 3600 & 3600 \\
\hline$R^{2}$ & & 0.208 & 0.188 & 0.208 & 0.266 \\
\hline
\end{tabular}

${ }^{\star} p<0.10,{ }^{\star \star} p<0.05,{ }^{\star \star \star} p<0.01$.

while offline markets tend to use concise definitions, this study is more suitable as a reference for offline rather than online slogans. Fourth, the survey has a limited sample; the mean and median age distribution of the sample is around 55 years, which does not effectively reflect the knowledge and preferences of young consumers for EFF produce.

In the literature on the marketing of EFF produce in Japan, few studies focus on consumer decision-making regarding EFF produce. This study fills a research gap by showing how consumer information can be used to market more effectively. We recommend more offline sales combined with community marketing, with the focus of the seller being more on the freshness, taste, and reasonable pricing of the EFF produce itself.

Because consumers are extremely sensitive to the price of agricultural produce, EFF produce in Japan is costlier than ordinary agricultural produce. In the future, we seek to shift part of our attention to explain the production and cost characteristics of Japanese EFF produce through empirical analysis.

In addition to reducing the cost of EFF produce and enhancing their competitiveness in the market, sellers should design their advertising slogans appropriately. They must combine online and brick-and-mortar storefronts to target different groups of consumers accurately and effectively. Effectively using information transmission to enhance the degree of recognition of consumers living in the same community could be a crucial link in the promotion of EFF produce.
Acknowledgements: This study was supported by the Japan Society for the Promotion of Science Core-to-Core Program - Advanced Research Networks (the establishment of an international agricultural immunology research-core for a quantum improvement in food safety).

\section{Appendix: Choice experiment set selected through the $R$ package.}

\begin{tabular}{llll}
\hline & Cabbage & Tomato & Carrot \\
\hline 1 & $(260, \mathrm{~S}),(200, \mathrm{~N})$ & $(210, \mathrm{~S}),(170, \mathrm{~S})$ & $(400, \mathrm{~N}),(250, \mathrm{O})$ \\
2 & $(200, \mathrm{O}),(170, \mathrm{O})$ & $(250, \mathrm{~N}),(210, \mathrm{~S})$ & $(200, \mathrm{~S}),(350, \mathrm{~S})$ \\
3 & $(140, \mathrm{O}),(230, \mathrm{~N})$ & $(330, \mathrm{~N}),(330, \mathrm{O})$ & $(250, \mathrm{~N}),(400, \mathrm{~S})$ \\
4 & $(260, \mathrm{~N}),(200, \mathrm{O})$ & $(170, \mathrm{~S}),(290, \mathrm{~N})$ & $(300, \mathrm{O}),(300, \mathrm{~S})$ \\
5 & $(170, \mathrm{~S}),(260, \mathrm{~N})$ & $(170, \mathrm{O}),(250, \mathrm{~S})$ & $(400, \mathrm{~S}),(300,0)$ \\
6 & $(200, \mathrm{~N}),(260, \mathrm{~S})$ & $(250, \mathrm{~S}),(330, \mathrm{~N})$ & $(350, \mathrm{~S}),(400, \mathrm{~N})$ \\
7 & $(170,0),(170, \mathrm{~S})$ & $(290, \mathrm{~N}),(170,0)$ & $(250,0),(250, \mathrm{~N})$ \\
8 & $(230, \mathrm{~N}),(140,0)$ & $(330,0),(250, \mathrm{~N})$ & $(300, \mathrm{~S}),(200, \mathrm{~S})$ \\
\hline
\end{tabular}

Unit: Yen; (0: organic S: specially cultivated $\mathrm{N}$ : normal).

\section{References}

Aizaki, H. 2005. "Choice Experiment Analysis of Consumers' Preference for Ecologically Friendly Rice.” Agricultural Information Research 14 (2): 85-96. 
Aizaki, H., and K. Nishimura. 2007. "Introduction to Choice Experiments Using R." Technical Report of the National Institute for Rural Engineering 206: 151-73.

Aizaki, H., and K. Nishimura. 2008. "Design and Analysis of Choice Experiments Using R: A Brief Introduction.” Agricultural Information Research 17 (2): 86-94.

Britwum, K., J. C. Bernard, and S. E. Albrecht. 2021. "Does Importance Influence Confidence in Organic Food Attributes?” Food Quality and Preference 87: 104056.

Carfora, V., C. Cavallo, D. Caso, T. Del Giudice, B. De Devitiis, R. Viscecchia, G. Nardone, and G. Cicia. 2019. "Explaining Consumer Purchase Behavior for Organic Milk: Including Trust and Green Self-Identity within the Theory of Planned Behavior.” Food Quality and Preference 76: 1-9.

Castle, L. F., K. Colgrove, C. Wells, and A. Henneman. 2019. "Comparing Website Data from Food Newsletter Subscribers with General 'Organic' Search Traffic Data." Journal of Nutrition Education and Behavior 51 (7): S124-5.

Galesic, M., and M. Bosnjak. 2009. "Effects of Questionnaire Length on Participation and Indicators of Response Quality in a Web Survey." Public Opinion Quarterly 73 (2): 349-60.

Greene, W. H. 2008. Econometric Analysis, 6th ed. New York: Pearson Education.

Hilverda, F., M. Kuttschreuter, and E. Giebels. 2017. "Social Media Mediated Interaction with Peers, Experts and Anonymous Authors: Conversation Partner and Message Framing Effects on Risk Perception and Sense-Making of Organic Food." Food Quality and Preference 56: 107-18.

Hoffman, S. D., and G. J. Duncan. 1988. "Multinomial and Conditional Logit Discrete-Choice Models in Demography.” Demography 25 (3): 415-27.

Hosono, H., and Y. Nakashima. 2011. "Consumer Confidence and Behavior Around Food Accidents." Journal of Food System Research 18 (3): 215-21 (in Japanese).

Huang, J., H. Qiu, J. Bai, and C. Pray. 2006. “Awareness, Acceptance of and Willingness to Buy Genetically Modified Foods in Urban China." Appetite 46 (2): 144-51.

Lian, Y., L. Wensu, and H. Bihong. 2014. "The Impact of Children Migration on the Health and Life Satisfaction of Parents Left behind." China Economic Quarterly 14 (1): 185-202 (in Chinese).

Liu, C., R. R. Sinkovics, N. Pezderka, and P. Haghirian. 2012. "Determinants of Consumer Perceptions Toward Mobile Advertising: A Comparison between Japan and Austria." Journal of Interactive Marketing 26 (1): 21-32.

Liu, R., Z. Gao, H. A. Snell, and H. Ma. 2020. "Food Safety Concerns and Consumer Preferences for Food Safety Attributes: Evidence from China." Food Control 112: 107-57.

Long, S. J. 1997. Regression Models for Categorical and Limited Dependent Variables, Advanced Quantitative Techniques in the Social Sciences. New York: SAGE Publications, Inc.

Ministry of Agriculture, Forestry and Fisheries Japan (MAFF). 2019. The State of Organic Agricultural. https://www.maff.go.jp/j/seisan/ kankyo/yuuki/attach/pdf/meguji-full.pdf (accessed July 10, 2020).

Mineki, M., K. Sakamoto, Y. Ishii, A. Fujii, Y. Niizawa, T. Kawai, and A. Kanatani. 2001. "The Relationship between Food Market and Consumer Behavior in Food Environment: Distribution and
Consumption of Organic Agriculture Products." Journal of Cookery Science of Japan 34 (2): 214-23 (in Japanese).

Moriuchi, E., and I. Takahashi. 2018. "An Empirical Investigation of the Factors Motivating Japanese Repeat Consumers to Review Their Shopping Experiences." Journal of Business Research 82: 381-90.

Ngo, H. M., R. Liu, M. Moritaka, and S. Fukuda. 2020. “Urban Consumer Trust in Safe Vegetables in Vietnam: The Role of Brand Trust and the Impact of Consumer Worry about Vegetable Safety." Food Control 108: 106856.

Ogawa, K. 2001. "The Japanese Agricultural Standards and Organic Certification System: An Approach with Information Economics." Agricultural Economics Papers of Kobe University 34: 21-8 (in Japanese).

Ohashi, M., K. Yagi, and Y. Naito. 2017. "Effect of Consumer Knowledge on Evaluation and Purchase of Regional Brands: Survey on Kagoshima, Kurobuta, Joshu Mugibuta, and Tankaku in Tokyo and in the Prefectures of Production." Journal of Rural Economics 89 (4): 301-6 (in Japanese).

Oura, Y., K. Yoshinobu, H. Aizaki, and K. Sato. 2002. "Estimation for Brand Power on Fresh Vegetables and Fruits Producing Districts with Choice-Based Conjoint Analysis." Japanese Journal of Farm Management 40 (1): 106-11 (in Japanese).

Parves, S., T. Tarafder, P. David, and H. Joanna. 2020. “IntentionBehaviour Gap and Perceived Behavioural Control-Behaviour Gap in Theory of Planned Behaviour: Moderating Roles of Communication, Satisfaction and Trust in Organic Food Consumption." Food Quality and Preference 81: 103-838.

Pearson, D., J. Henryks, and H. Jones. 2011. "Organic Food: What We Know (and Do Not Know) about Consumers." Renewable Agriculture \& Food Systems 26 (2): 171-7.

Prescott, J., O. Young, L. O’Neill, N. J. N. Yau, and R. Stevens. 2002. "Motives for Food Choice: A Comparison of Consumers from Japan, Taiwan, Malaysia and New Zealand." Food Quality and Preference 13 (7-8): 489-95.

Rabadán, A., M. Díaz, M. Brugarolas, and R. Bernabéu. 2020. “Why Don't Consumers Buy Organic Lamb Meat? A Spanish Case Study." Meat Science 162: 108-24.

Roitner-Schobesberger, B. R., I. Darnhofer, S. Somsook, and C. R. Vogl. 2008. "Consumer Perceptions of Organic Foods in Bangkok, Thailand." Food Policy 33 (2): 112-21.

Sadiq, M. A., B. Rajeswari, L. Ansari, and M. D. Kirmani. 2021. "The Role of Food Eating Values and Exploratory Behaviour Traits in Predicting Intention to Consume Organic Foods: An Extended Planned Behaviour Approach." Journal of Retailing \& Consumer Services 59: 102-352.

Saba, A., and F. Messina. 2003. "Attitudes towards Organic Foods and Risk/Benefit Perception Associated with Pesticides." Food Quality and Preference 14 (8): 637-45.

Sakai, Y., K. Yanehashi, E. Yiu, and N. Yagi. 2018. "The Preference of People in Singapore toward Japanese Seafood Products: An Ordered Choice Analysis.” Nippon Suisan Gakkaishi 84 (5): 872-82 (in Japanese).

Sato, M., M. Sakagami, Y. Suzuki, K. Ueta, and H. Takatsuki. 2005. “An Economic Analysis of Consumers' Preference toward Organic Vegetables with Special Reference to the Local Organic Material Circulation and Certification Labels." Environmental Sciences 18 (3): 243-55 (in Japanese). 
Shafie, F. A., and D. Rennie. 2012. "Consumer Perceptions towards Organic Food, Procedia." Social and Behavioral Sciences 49: 360-7.

Takahashi, R., Y. Todo, and Y. Funaki. 2018. "How Can We Motivate Consumers to Purchase Certified Forest Coffee? Evidence from a Laboratory Randomized Experiment Using Eye-Trackers." Ecological Economics 150: 107-21.

Takashino, N., Y. Chiba, and K. Fuyuki. 2019. "Consumer Preference for Immune-Health Promoted Pork.” Journal of Rural Society \& Economics 36 (2): 1-8.

Taniguchi, Y. 2012. The Role of Trust in the Market Penetration of Organic Food Products: General Confidence and Organic Vegetable Purchasing Channel Selection. Food System Research Association of Japan (in Japanese).

Vitters $\varnothing$, G., and T. Tangeland. 2015. "The Role of Consumers in Transitions towards Sustainable Food Consumption. The Case of Organic Food in Norway." Journal of Cleaner Production 92: 91-9.

Wang, E. S. T., and M. C. Tsai. 2019. "Effects of the Perception of Traceable Fresh Food Safety and Nutrition on Perceived Health Benefits, Affective Commitment, and Repurchase Intention.” Food Quality and Preference 78: 103723.

Yagishita, M., and M. Fuwa. 2016. Is the Association Between Educational Attainment and Marital Aspiration Linear? Comparison of Regression Models for Ordinal Variables, Vol. 96, 1-19. Tokyo: University of Tokyo Institute of Social Science Panel Survey (in Japanese).

Yano Research Institute Ltd. 2018. Organic Food Market 2018 in Japan (in Japanese). Also available at https://www. yanoresearch.com $/$ market_reports $/$ C60102400? returnPage $=$ \%2Fmarket_reports\%2FsearchMr.php\%3Fsearch_class\% 3D0\%26search_keyword\%3Dorganic. 